\title{
MAINTENANCE ALGORITHM AND MANAGEMENT SYSTEM OF SIDEWALK FACILITY
}

\author{
Lee-Kuo Lin \\ Civil Engineering Department, National Taipei University of Technology, Taipei, Taiwan, R.O.C, Iklin@ntut.edu.tw \\ Chen-You Jian \\ Civil Engineering Department, National Taipei University of Technology, Taipei, Taiwan, R.O.C
}

Follow this and additional works at: https://jmstt.ntou.edu.tw/journal

Part of the Civil and Environmental Engineering Commons

\author{
Recommended Citation \\ Lin, Lee-Kuo and Jian, Chen-You (2010) "MAINTENANCE ALGORITHM AND MANAGEMENT SYSTEM OF SIDEWALK \\ FACILITY," Journal of Marine Science and Technology. Vol. 18: Iss. 5, Article 13. \\ DOI: $10.51400 / 2709-6998.1923$ \\ Available at: https://jmstt.ntou.edu.tw/journal/vol18/iss5/13 \\ This Research Article is brought to you for free and open access by Journal of Marine Science and Technology. It has been \\ accepted for inclusion in Journal of Marine Science and Technology by an authorized editor of Journal of Marine Science and \\ Technology.
}




\title{
MAINTENANCE ALGORITHM AND MANAGEMENT SYSTEM OF SIDEWALK FACILITY
}

\author{
Lee-Kuo Lin* and Chen-You Jian*
}

Key words: infrastructure system, sidewalk facility, management system, maintenance algorithm, Delphi method, AHP, optimum decision.

\begin{abstract}
Sidewalk is one kind of infrastructure systems in each city, because every sidewalk facility is used by pedestrians, so the maintenance algorithm should be evaluated and worked with users' role. To echo this reasonable concept, this research investigates several using influence factors, which were collected and evaluated from pedestrians. For statistical analysis, scientific tools including Delphi method, analytic hierarchy process (AHP), and fuzzy theory were used to analyze and establish a preliminary evaluation model of sidewalk maintenance system. In order to use this model pragmatically, this research also establishes a portable prototype system at PDA hardware. With this portable system, inspectors can use PDA to investigate exist situations of sidewalks at the job site and collect defects into the system. Then this system can calculate all the investigation data of sidewalks to sort what section of sidewalk should be repaired first. So, through this prototype sidewalks management system, sidewalks maintenance can be made with an optimum decision.
\end{abstract}

\section{INTRODUCTION}

Infrastructure systems are strong irrelative with citizen's live-hood, especially for living serviceability quality. In general, there are seven categories within the infrastructure system, including [3]:

(1) Roads group: including roads, streets, bridges and tunnel.

(2) Transportation service group: including transit, rail, ports and airports.

(3) Water group: including water, waste water and all water system.

(4) Waste group: including solid and liquid wastes.

Paper submitted 01/16/09; revised 11/12/09; accepted 10/05/09. Author for correspondence: Lee-Kuo Lin (e-mail: lklin@ntut.edu.tw).

*Civil Engineering Department, National Taipei University of Technology, Taipei, Taiwan, R.O.C.
(5) Building group: including public building and out door sports.

(6) Energy production and distribution group: including electronic and gas.

(7) Others

In each country, sidewalk is one of the most usable facilities for every citizen, which supplies convenience communication hardware for citizens' walking. Depending on the development and improvement history, the facility of sidewalks not only provides walking function for people but also is a key index of each city's infrastructure performance. The development of each urban composes with essential factor, which is people, and walking is the necessary method for people to move around the urban region. Thus, an appropriate sidewalk system in a modern city must provide a safety, comfortable, and quick facilities for citizens to use. Although, there are lots of vehicles today, short distance transportation still needs to perform by walking. In general, there are several functions supplied with sidewalk facility [4]:

(1) To link building for people's communication.

(2) To show a city's townscape.

(3) To set up facilities, including traffic sign, street light and hydrant.

(4) To provide an emergency way when disaster occurring.

If made roads as blood vessels due to roads can let traffic transporting in all directions, then sidewalks can be made as the blood capillaries in each city [5]. So it's an important function for people to walk in a convenience sidewalk system. The evaluate and maintenance result of sidewalks system not only supply communication service but also create the utility of prettifying environment, entertaining, and so on. So an appropriate sidewalk system is a sign of modernization and advancement for each city.

It's an important issue for keeping sidewalk system in well condition to guarantee its performance. To develop a sidewalk evaluation algorithm, this research uses analysis tools of Delphi, analytic hierarchy process (AHP), and fuzzy theory by questionnaires to build up the model of assessing sidewalk conditions [6-8], and to establish the repair's priority. This research also uses computing technology to build up an analysis sys- 
System Phase

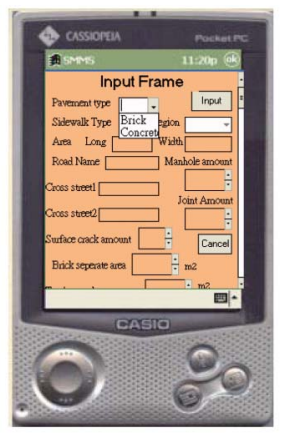

Recording basic data and condition outside.
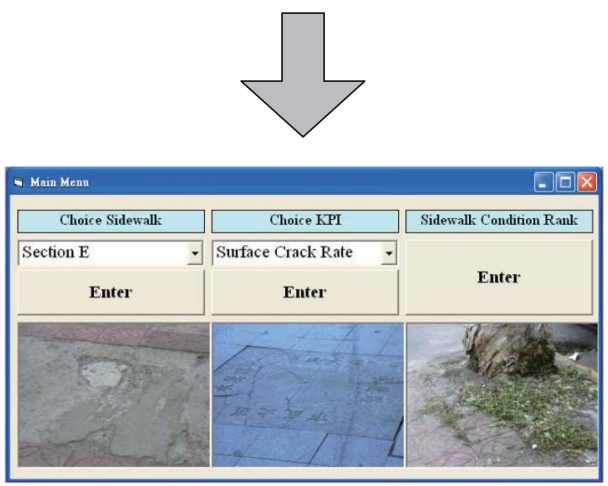

Analyzing inspection data inside.

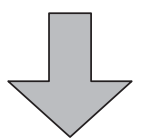

Providing analysis result to policymaker.
Analysis Model Phase

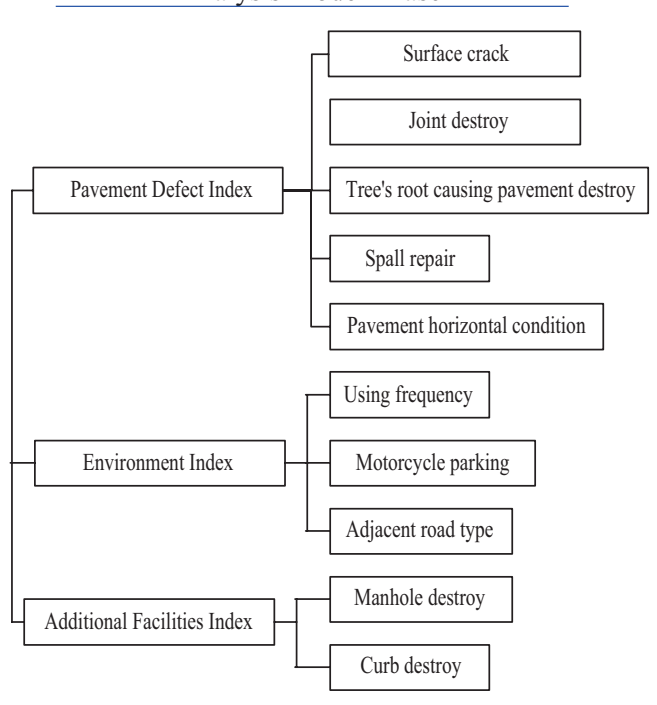

Providing assessment factor to record

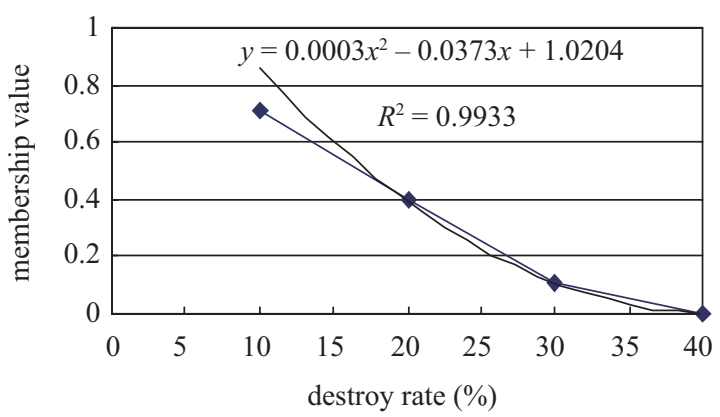

Providing assessment model to analyze

Fig. 1. The integration of maintenance system and assessment model.

tem which can record existing data of sidewalk at outside and analyze optimum maintenance decision at inside.

This sidewalks management system is developed with two modules: the first module is the assessment model of maintenance management; the second module is the analysis system includes portable recording system which was built on PDA and determining system which was built on PC. The relationship of both systems is as shown in Fig. 1.

\section{STRUCTURE DEVELOPMENT OF ASSESSMENT MODEL}

In general, there are two kinds of sidewalk, including concrete pavement and brick pavement [5]. There are three steps to build the sidewalk assessment model, (1) identifying the assessment factors, (2) identifying the relationship of assessment factors to calculate the weighting factors and (3) identifying the grade of assessment factors. According this procedure, the assessment model can be built.

\section{Identifying the Assessment Factors}

First, this research uses technical literatures and interviews several experts to build up the original questionnaire and influence hierarchy. Then, uses Delphi method (each item can select score from 1 to 5 in questionnaire) to make sure the ended item. It has two phases to ask the same pedestrians with questionnaires. In both phases, this research asks with 40 citizens. At both phases retrieve 36 citizens. According to this inspection, it can identify the item which pedestrians feel importance. Then, uses Delphi method to make revised questionnaire. Figures 2 and 3 are the final results.

\section{Identifying the Weighting of Key Performance Index (KPI)}

Because this hierarchy involves lots of index factors, so need to compare their relations to determine each weighting factor. This research uses analysis hierarchy process (AHP) method and questionnaire to drive the weighting factors. The analysis process of AHP is describing as follow. 


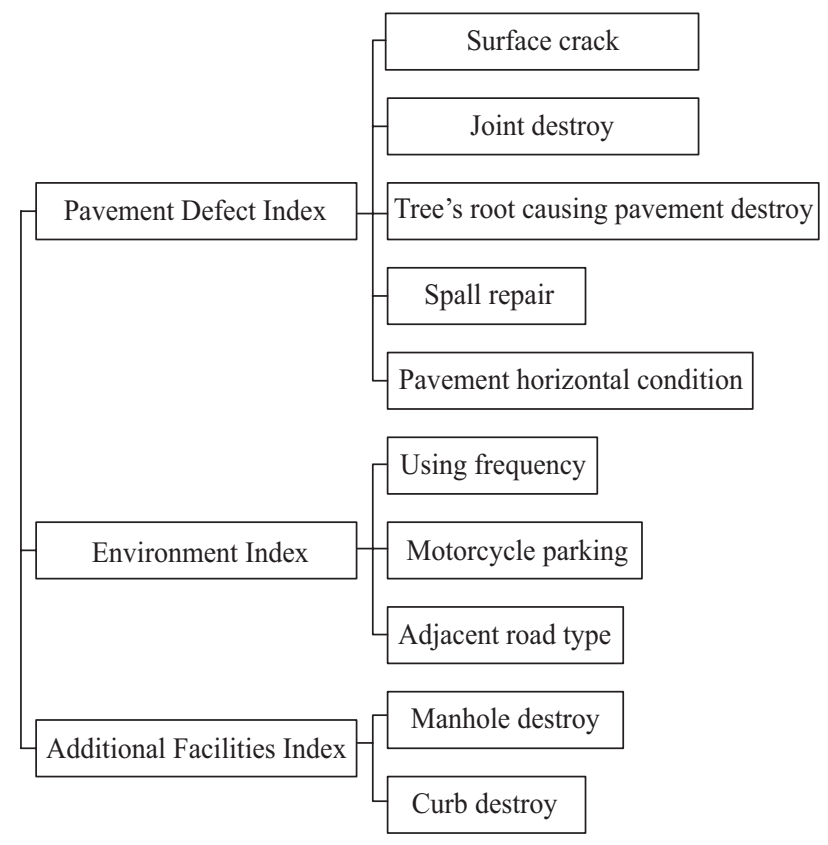

Fig. 2. The evaluation hierarchy of concrete pavement sidewalk.

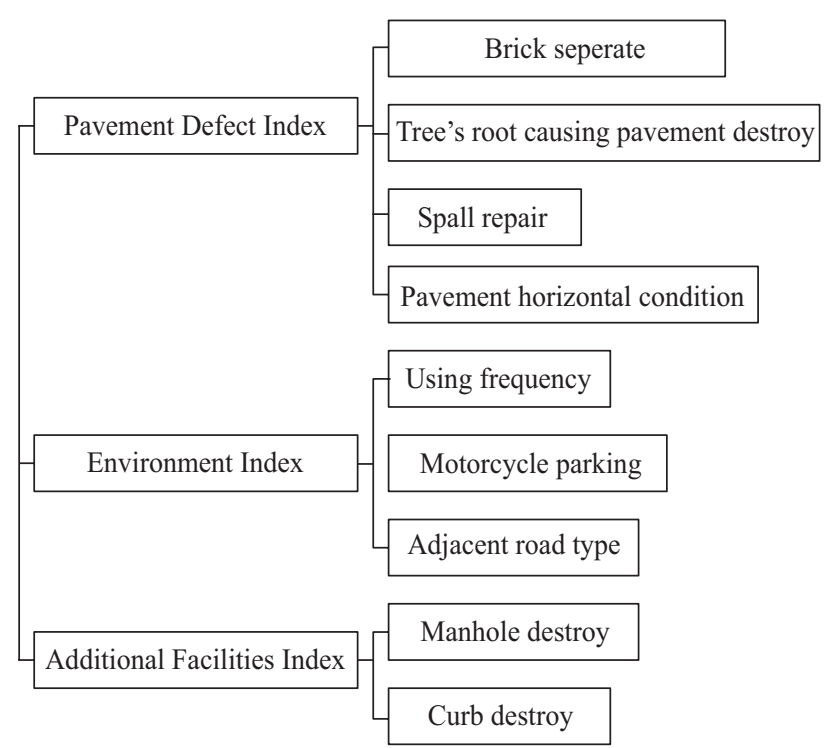

Fig. 3. The evaluation hierarchy of brick pavement sidewalk.

(1) Building up compare matrix: In order to compare each assessment factor, it must use nominal scale as a matrix to calculate. If a specific index contains $\mathrm{n}$ factors to analysis, it will have $n \times(n-1) / 2$ pairs to compare.

$$
\mathrm{A}=\left[\begin{array}{ccccc}
1 & a_{12} & a_{13} & \cdots & a_{1 n} \\
a_{21} & 1 & \vdots & \vdots & a_{2 n} \\
\vdots & \vdots & 1 & \vdots & \vdots \\
\vdots & \vdots & \vdots & 1 & \vdots \\
a_{n 1} & a_{n 2} & \cdots & \vdots & 1
\end{array}\right]
$$

Table 1. A calculating example of weighting factor.

\begin{tabular}{|c|c|c|c|c|c|c|}
\hline Item & $\begin{array}{c}\text { Factor } \\
1\end{array}$ & $\begin{array}{c}\text { Factor } \\
2\end{array}$ & $\begin{array}{c}\text { Factor } \\
3\end{array}$ & $\begin{array}{c}\text { Factor } \\
4\end{array}$ & Geometric mean & Weighting \\
\hline $\begin{array}{c}\text { Factor } \\
1\end{array}$ & 1 & 3 & 5 & 7 & $\sqrt[4]{1 \times 3 \times 5 \times 7}=3.20$ & $3.20 / 5.93=0.540$ \\
\hline $\begin{array}{c}\text { Factor } \\
2\end{array}$ & $1 / 3$ & 1 & 5 & 7 & $\sqrt[4]{\frac{1}{3} \times 3 \times 5 \times 7}=1.85$ & $1.85 / 5.93=0.312$ \\
\hline $\begin{array}{c}\text { Factor } \\
3\end{array}$ & $1 / 5$ & $1 / 5$ & 1 & 3 & $\sqrt[4]{\frac{1}{5} \times \frac{1}{5} \times 1 \times 3}=0.59$ & $0.59 / 5.93=0.099$ \\
\hline $\begin{array}{c}\text { Factor } \\
4\end{array}$ & $1 / 7$ & $1 / 7$ & $1 / 3$ & 1 & $\sqrt[4]{\frac{1}{7} \times \frac{1}{7} \times \frac{1}{3} \times 1}=0.29$ & $0.29 / 5.93=0.049$ \\
\hline \multicolumn{7}{|c|}{ Total } \\
\hline
\end{tabular}

Table 2. The list of random index (R.I.).

\begin{tabular}{|c|c|c|c|c|c|c|c|c|}
\hline $\mathrm{N}$ & 1 & 2 & 3 & 4 & 5 & 6 & 7 & 8 \\
\hline R.I. & 0.00 & 0.00 & 0.58 & 0.90 & 1.12 & 1.24 & 1.32 & 1.41 \\
\hline $\mathrm{N}$ & 9 & 10 & 11 & 12 & 13 & 14 & 15 & \\
\hline R.I. & 1.45 & 1.49 & 1.51 & 1.48 & 1.56 & 1.57 & 1.59 & \\
\hline
\end{tabular}

Table 3. An example of calculating $\lambda_{\max }$.

\begin{tabular}{|c|c|c|c|c|c|c|}
\hline Item & $\begin{array}{c}\text { Factor } \\
1\end{array}$ & $\begin{array}{c}\text { Factor } \\
2\end{array}$ & $\begin{array}{c}\text { Factor } \\
3\end{array}$ & $\begin{array}{c}\text { Factor } \\
4\end{array}$ & $\begin{array}{c}\text { Row } \\
\text { amount }\end{array}$ & $\begin{array}{c}\text { Row } \\
\text { amount/weighting }\end{array}$ \\
\hline $\begin{array}{c}\text { Factor } \\
1\end{array}$ & 0.54 & 0.93 & 0.5 & 0.35 & 2.32 & $2.32 / 0.54=4.296$ \\
\hline $\begin{array}{c}\text { Factor } \\
2\end{array}$ & 0.18 & 0.31 & 0.5 & 0.35 & 1.34 & $1.34 / 0.31=4.323$ \\
\hline $\begin{array}{c}\text { Factor } \\
3\end{array}$ & 0.108 & 0.062 & 0.1 & 0.15 & 0.42 & $0.42 / 0.1=4.200$ \\
\hline $\begin{array}{c}\text { Factor } \\
4\end{array}$ & 0.077 & 0.044 & 0.033 & 0.05 & 0.204 & $0.204 / 0 / 05=4.080$ \\
\hline \multicolumn{7}{|c|}{$\lambda_{\max }$} \\
\hline \multicolumn{7}{|c|}{} \\
\hline
\end{tabular}

(2) Calculating weighting: The calculating method is as shown in formula (1). And the calculating example is as shown in Table 1.

$$
w i=\frac{a_{i j}}{G M_{i}}
$$

$G M_{i}=$ the geometric mean of one row in compare matrix. $i=$ row number.

$j=$ column number.

$a_{i j}=$ factor $i$ compare with factor $j$.

(3) Calculating consistency ration (C.R.): In order to get consistency ration (C.R.) value, it must calculate with formula (2), (3) and (4). And the calculating example of is as shown in Tables 2 and 3. 
Table 4. An example of AHP questionnaire.

\begin{tabular}{|c|c|c|c|c|c|c|c|c|c|c|}
\hline \multicolumn{11}{|c|}{ The assessment factors of first rank } \\
\hline $\begin{array}{l}\text { Assessment } \\
\text { factors }\end{array}$ & 9 & 7 & 5 & 3 & 1 & 3 & 5 & 7 & 9 & Assessment factors \\
\hline \multirow{2}{*}{$\begin{array}{c}\text { Pavement } \\
\text { defect index }\end{array}$} & & & & & & & $\sqrt{ }$ & & & Environment index \\
\hline & & & & & $\sqrt{ }$ & & & & & Addition facilities index \\
\hline $\begin{array}{l}\text { Environment } \\
\text { index }\end{array}$ & & & & $\sqrt{ }$ & & & & & & Addition facilities index \\
\hline
\end{tabular}

Table 5. An example of pass ratio with some assessment factors.

\begin{tabular}{|c|c|c|c|c|c|c|c|}
\hline & $\begin{array}{c}\text { Assessment } \\
\text { factors }\end{array}$ & $\begin{array}{c}\text { C.R. } \\
0.1 \\
\end{array}$ & $\begin{array}{l}\text { Pass } \\
\text { ratio }\end{array}$ & $\begin{array}{c}\text { C.R. } \\
0.2 \\
\end{array}$ & $\begin{array}{l}\text { Pass } \\
\text { ratio }\end{array}$ & $\begin{array}{c}\text { C.R. } \\
0.3 \\
\end{array}$ & $\begin{array}{l}\text { Pass } \\
\text { ratio }\end{array}$ \\
\hline & $\begin{array}{l}\text { Concrete } \\
\text { pavement }\end{array}$ & 0.39 & \multirow{2}{*}{100} & 0.39 & \multirow{2}{*}{100} & 0.39 & \multirow{2}{*}{100} \\
\hline & $\begin{array}{c}\text { Brick } \\
\text { pavement }\end{array}$ & 0.61 & & 0.61 & & 0.61 & \\
\hline \multirow{3}{*}{$\begin{array}{l}\text { First } \\
\text { rank }\end{array}$} & $\begin{array}{c}\text { Pavement } \\
\text { defect index }\end{array}$ & 0.32 & \multirow{3}{*}{41.38} & 0.31 & \multirow{3}{*}{58.62} & 0.31 & \multirow{3}{*}{86.21} \\
\hline & $\begin{array}{l}\text { Environment } \\
\text { index }\end{array}$ & 0.31 & & 0.31 & & 0.34 & \\
\hline & $\begin{array}{c}\text { Addition } \\
\text { facilities index }\end{array}$ & 0.37 & & 0.38 & & 0.35 & \\
\hline
\end{tabular}

$$
\begin{gathered}
\lambda_{\max }=\sum_{j=1}^{n} a_{i j} \times w_{i} \quad i=1 \sim n \\
\text { C.I. }=\frac{\lambda_{\max }-n}{n-1} \\
\text { C.R. }=\frac{\text { C.I. }}{\text { R.I. }}
\end{gathered}
$$

This inspection had asked 40 citizens, and retrieved 36 questionnaires. In order to calculate weighting index of the assessment factors, this research pairs each assessment factors to compare and figure out weighting index. It's shown in Table 4. Before calculating weighting, it must to check C.R. values to know discrete degree of each questionnaire. The pass ration, which uses 0.1 as threshold value isn't well, so this study changes threshold value to 0.3 . After this step, the pass ratio upgrade to $80 \%$. The example of calculating process is shown in Table 5. Final weighting index are shown in Tables 6 and 7.

\section{Establishing the Level of KPI}

Because each assessment factor has its different cognition, so it must be identified with every situation in each factor. This research uses fuzzy theory to statistics the cognition of citizens from these assessment factors. The membership value calculated from questionnaire to derive three grades of its mem-

\begin{tabular}{|c|c|c|c|c|}
\hline 1st layer & $\begin{array}{c}\text { Weighting } \\
\text { Factors } \\
\text { (W1) }\end{array}$ & 2nd layer & $\begin{array}{c}\text { Weighting } \\
\text { Factors } \\
\text { (W2) }\end{array}$ & $\begin{array}{c}\text { Final } \\
\text { Weighting } \\
(\mathrm{W} 1 \times \mathrm{W} 2)\end{array}$ \\
\hline \multirow{5}{*}{$\begin{array}{c}\text { Pavement } \\
\text { Defect } \\
\text { Index }\end{array}$} & \multirow{5}{*}{0.31} & Spall repair & 0.17 & 0.05 \\
\hline & & $\begin{array}{l}\text { Tree's root causing } \\
\text { pavement destroy }\end{array}$ & 0.21 & 0.07 \\
\hline & & $\begin{array}{l}\text { Pavement } \\
\text { horizontal } \\
\text { condition }\end{array}$ & 0.20 & 0.06 \\
\hline & & Joint destroy & 0.18 & 0.06 \\
\hline & & Surface crack & 0.24 & 0.07 \\
\hline \multirow{3}{*}{$\begin{array}{c}\text { Environment } \\
\text { Index }\end{array}$} & \multirow{3}{*}{0.34} & Using frequency & 0.35 & 0.12 \\
\hline & & $\begin{array}{l}\text { Motorcycle } \\
\text { parking }\end{array}$ & 0.34 & 0.12 \\
\hline & & Adjacent road type & 0.31 & 0.11 \\
\hline \multirow{2}{*}{$\begin{array}{c}\text { Additional } \\
\text { Facilities } \\
\text { Index }\end{array}$} & \multirow{2}{*}{0.35} & Manhole destroy & 0.53 & 0.19 \\
\hline & & Curb destroy & 0.47 & 0.16 \\
\hline
\end{tabular}
bership function within each assessment factor. The question-
Table 6. Weighting factors of concrete pavement sidewalk.

\begin{tabular}{|c|c|c|c|c|}
\hline 1st layer & $\begin{array}{c}\text { Weighting } \\
\text { Factors } \\
\text { (W1) }\end{array}$ & 2nd layer & $\begin{array}{c}\text { Weighting } \\
\text { Factors } \\
\text { (W2) }\end{array}$ & $\begin{array}{c}\begin{array}{c}\text { Final } \\
\text { weighting } \\
(\mathrm{W} 1 \times \mathrm{W} 2)\end{array} \\
\end{array}$ \\
\hline \multirow{4}{*}{$\begin{array}{c}\text { Pavement } \\
\text { Defect Index }\end{array}$} & \multirow{4}{*}{0.31} & Brick separate & 0.31 & 0.10 \\
\hline & & $\begin{array}{l}\text { Tree's root causing } \\
\text { pavement destroy }\end{array}$ & 0.18 & 0.06 \\
\hline & & Spall repair & 0.24 & 0.07 \\
\hline & & $\begin{array}{l}\text { Pavement } \\
\text { horizontal } \\
\text { condition }\end{array}$ & 0.27 & 0.08 \\
\hline \multirow{3}{*}{$\begin{array}{c}\text { Environment } \\
\text { Index }\end{array}$} & \multirow{3}{*}{0.34} & Using frequency & 0.35 & 0.12 \\
\hline & & $\begin{array}{l}\text { Motorcycle } \\
\text { parking }\end{array}$ & 0.34 & 0.12 \\
\hline & & Adjacent road type & 0.31 & 0.11 \\
\hline & \multirow{2}{*}{0.35} & Manhole destroy & 0.53 & 0.19 \\
\hline & & Curb destroy & 0.47 & 0.16 \\
\hline
\end{tabular}

Table 7. Weighting factors of brick pavement sidewalk.

naire sample is shown in Table 8 . In Table 9, this study counts each assessment factor, and then normalizes to figure out its membership values. For example, the calculation results of joint destroy factor are shown in Figs. 4 to 7.

\section{CALCULATING EXPLATION}

In order to explain the calculation process of assessment model, the following description is depended on the building up process of the sidewalk assessment model which is shown in Fig. 8.

1. Establish AHP questionnaire and assessment hierarchy. 
Table 8. An example of fuzzy questionnaire.

\begin{tabular}{|c|c|c|c|}
\hline Grade & A & B & C \\
\hline $\begin{array}{c}\text { Joint destroy } \\
\text { (defect length/total defect) }\end{array}$ & \multicolumn{3}{|c|}{ Grade } \\
\hline Under $10 \%$ & \multicolumn{2}{|c|}{ A } \\
\hline $20 \%$ & A \\
\hline $30 \%$ & A \\
\hline $40 \%$ & B \\
\hline $50 \%$ & B \\
\hline $60 \%$ & C \\
\hline $70 \%$ & C \\
\hline $80 \%$ & C \\
\hline Above $90 \%$ & C \\
\hline
\end{tabular}

Table 9. Calculating process of membership value with joint destroys.

\begin{tabular}{|c|c|c|c|c|c|c|c|c|c|}
\hline \multicolumn{7}{|c|}{ Joint destroy ratio (\%) (Joint destroy number/Total joint number) } \\
\hline Grade & $\begin{array}{c}\text { Under } \\
10\end{array}$ & 20 & 30 & 40 & 50 & 60 & 70 & 80 & $\begin{array}{c}\text { Above } \\
90\end{array}$ \\
\hline A & 28 & 20 & 11 & 3 & 0 & 0 & 0 & 0 & 0 \\
\hline $\begin{array}{c}\text { A } \\
\text { (membership value) }\end{array}$ & 1.00 & 0.71 & 0.39 & 0.11 & 0 & 0 & 0 & 0 & 0 \\
\hline B & 0 & 7 & 14 & 17 & 15 & 8 & 1 & 1 & 1 \\
\hline $\begin{array}{c}\text { B } \\
\text { (membership value) }\end{array}$ & 0 & 0.41 & 0.82 & 1.00 & 0.88 & 0.47 & 0.06 & 0.06 & 0.06 \\
\hline C & 1 & 2 & 4 & 9 & 14 & 21 & 28 & 28 & 28 \\
\hline $\begin{array}{c}\text { C } \\
\text { (membership value) }\end{array}$ & 0.04 & 0.07 & 0.14 & 0.32 & 0.50 & 0.75 & 1.00 & 1.00 & 1.00 \\
\hline
\end{tabular}

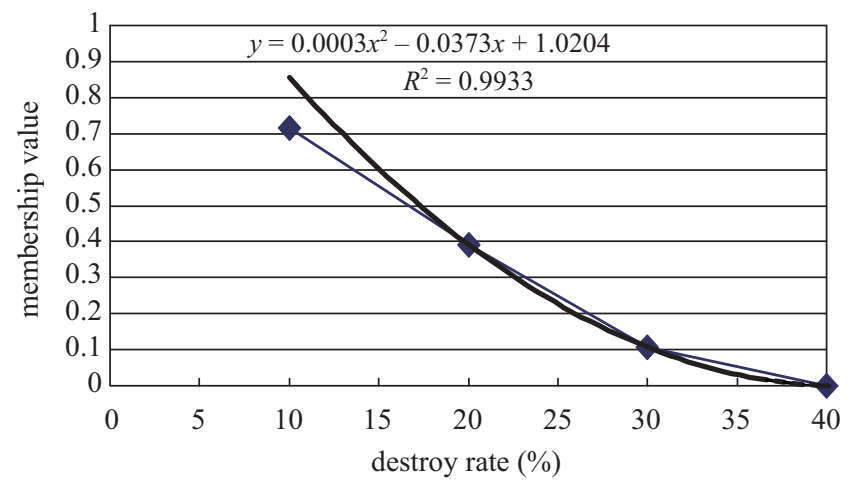

Fig. 4. Grade A of joint destroy.

For example, Table 4 is one of the questionnaire's result.

2. Confirming the weighting of key performance index.

There are three steps to conform the weighting factors.

(1) Calculate the weighting of factors. Depending on the questionnaires' result, the weighting factor can be calculated as shown in Fig. 9.

(2) Calculate the value of: The calculation process is shown in Fig. 10

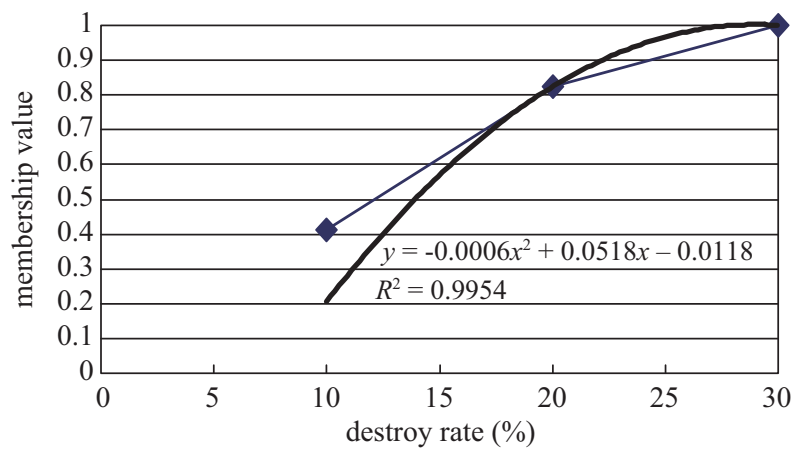

Fig. 5. Grade BL of joint destroy.

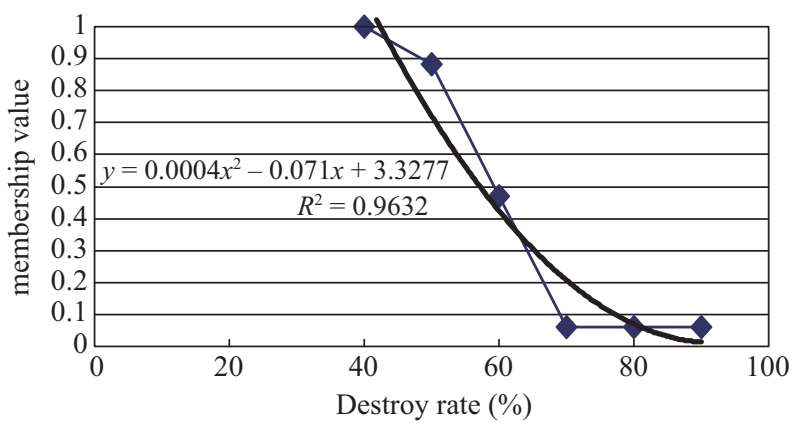

Fig. 6. Grade BR of joint destroy.

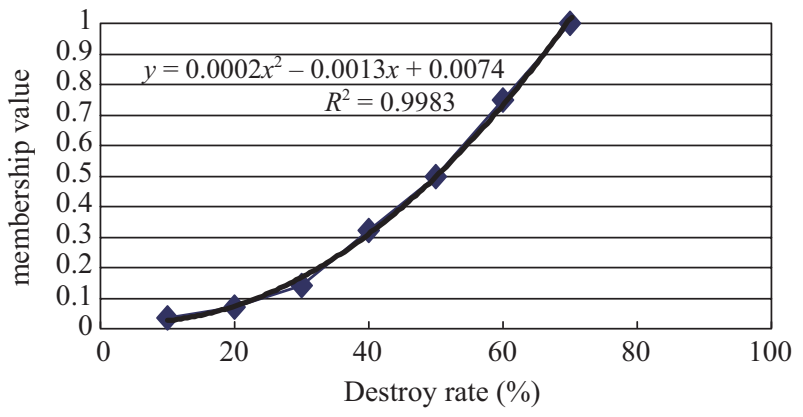

Fig. 7. Grade $\mathrm{C}$ of joint destroy.

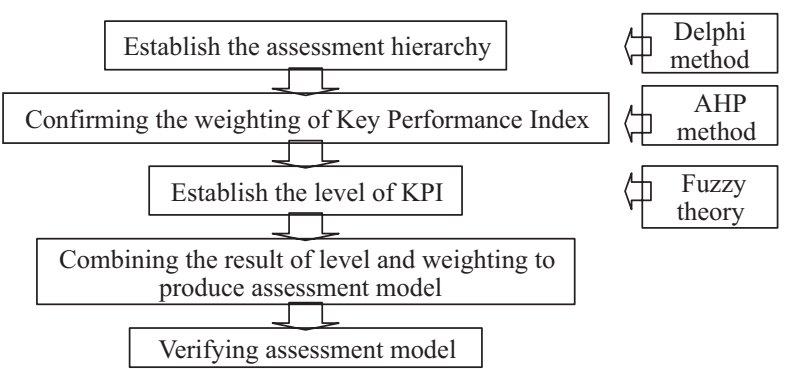

Fig. 8. Build up process of assessment model.

(3) Calculate the value of C.R. value: For example, when $n=3$, the C.R. value can be calculated by using the following equations, Table 3 is the calculation result. 


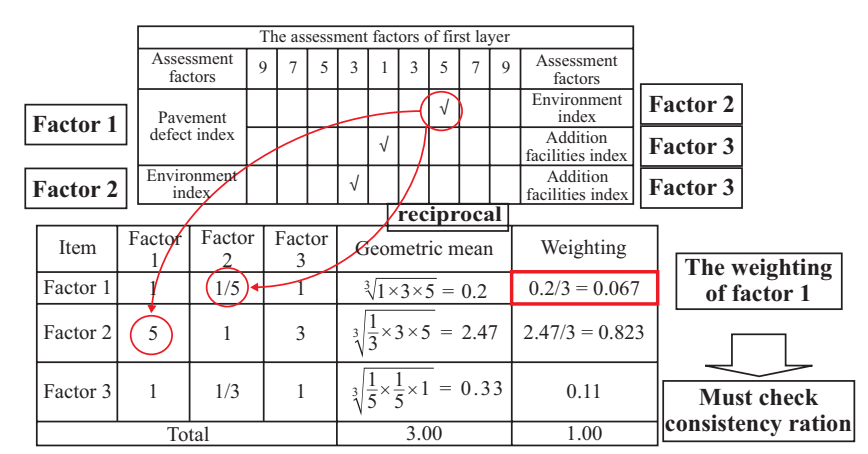

Fig. 9. Weighting factor calculation.

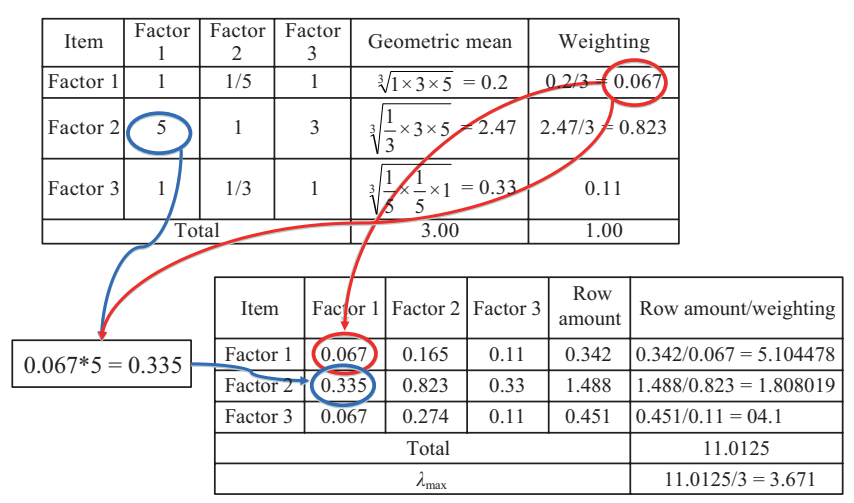

Fig. 10. $\lambda_{\max }$ calculation.

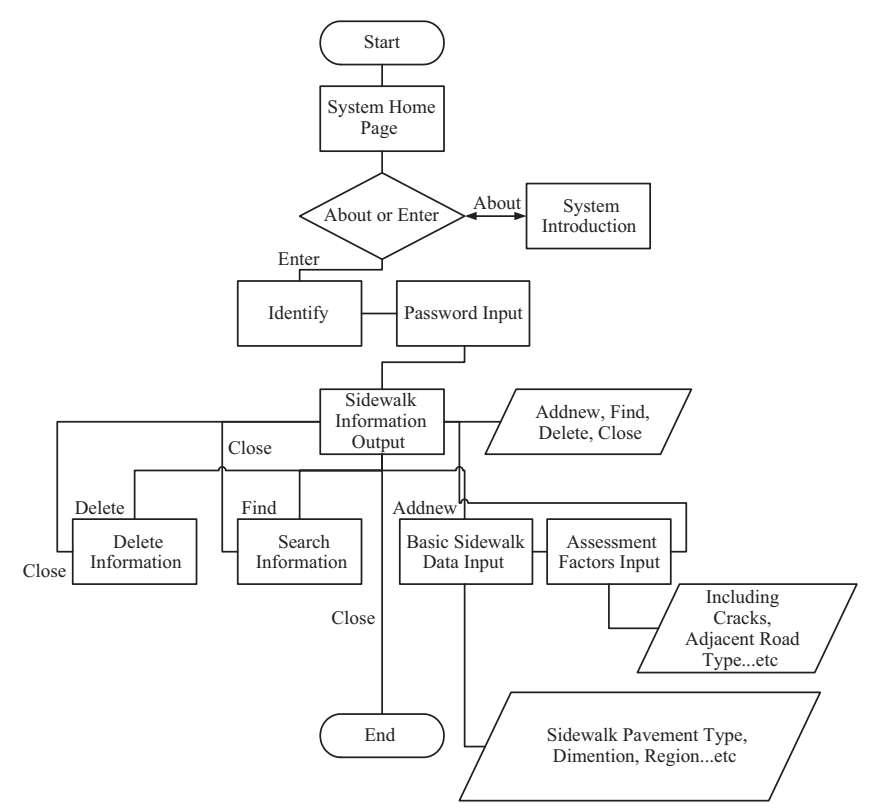

Fig. 11. The flow chart of PDA system.

$$
\begin{gathered}
\text { C.I. }=\frac{\lambda_{\max }-n}{n-1}=\frac{3.671-3}{3-1}=0.3355 \\
\text { C.R. }=\frac{\text { C.I. }}{\text { R.I. }}=\frac{0.3355}{0.58}=0.58
\end{gathered}
$$

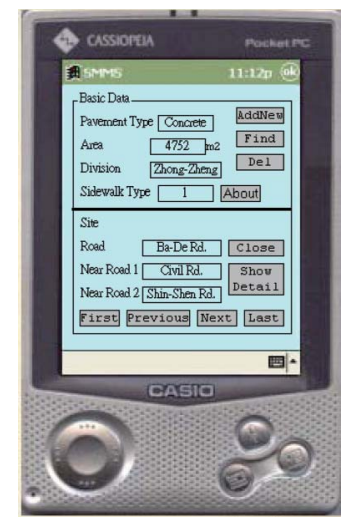

Fig. 12. General information of sidewalk.

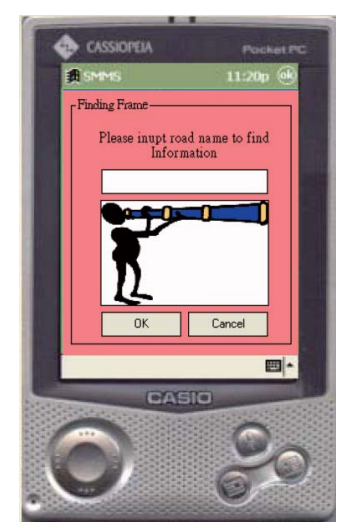

Fig. 14. The input screen for finding specific sidewalk.

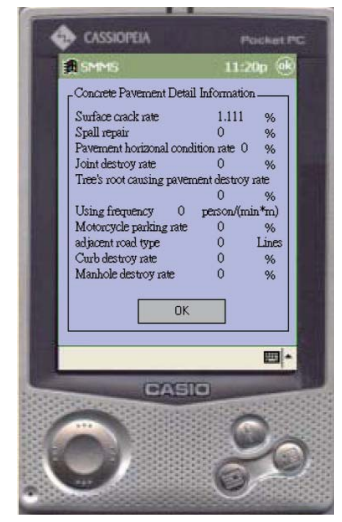

Fig. 13. Detail data of sidewalk.

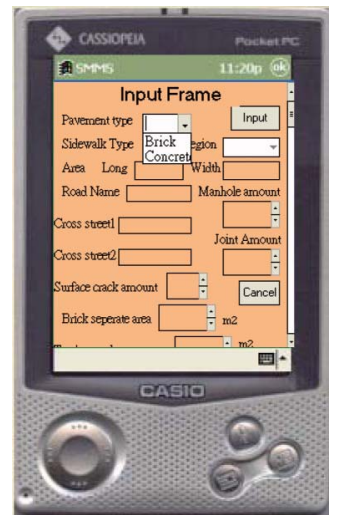

Fig. 15. Adding new data screen.

\section{MAINTENANCE SYSTEM DEMONSTRATION}

There are two modules of this sidewalk maintenance management system. The first module uses personal digital assistant (PDA) to collect sidewalk conditions at the field. The second module uses PC to translate data from PDA and to analyze for deriving the condition result which can be compared for the maintenance priority.

\section{On-Site Use of This Portable System Development}

This research selects WinCE system as OS of PDA hardware and Embedded Visual Basic (EVB) as software. The development process is shown as Fig. 11. Once this PDA system is executed, the copyright description will automatically show on the screen. The program user can choose the "About" button to read introduction screen. The "Enter" button will allow user to get into ID check frame. Once the user inputs correct username and password, system can show the sidewalk basic data frame (Fig. 12). User can use "Next", "Previous", "First", and "Last" buttons to explore data and information. If any user wants to explore in detail data, user can select "Show Detail" button to look (Fig. 13). 


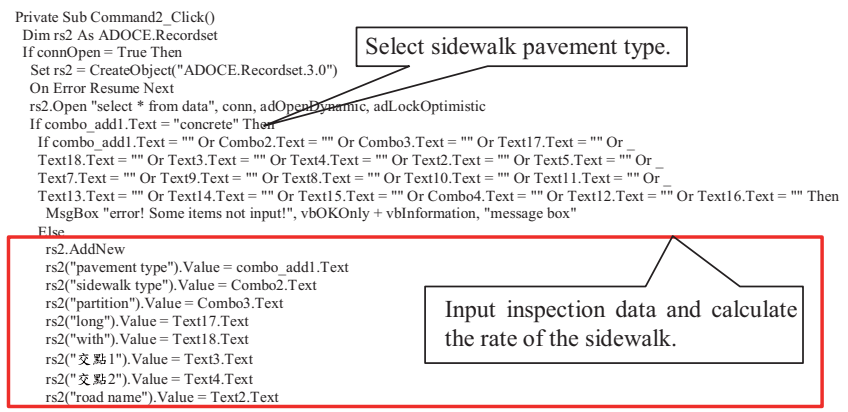

Fig. 16. Program codes of "select pavement type" and "Addnew" function.

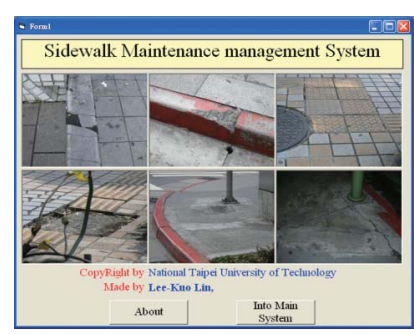

Fig. 17. System homepage.

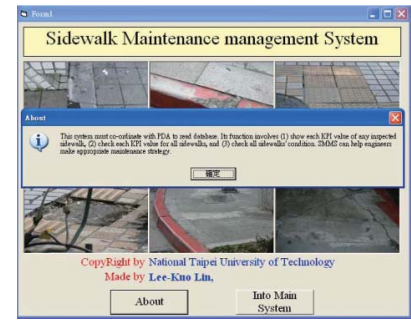

Fig. 18. System introduction.

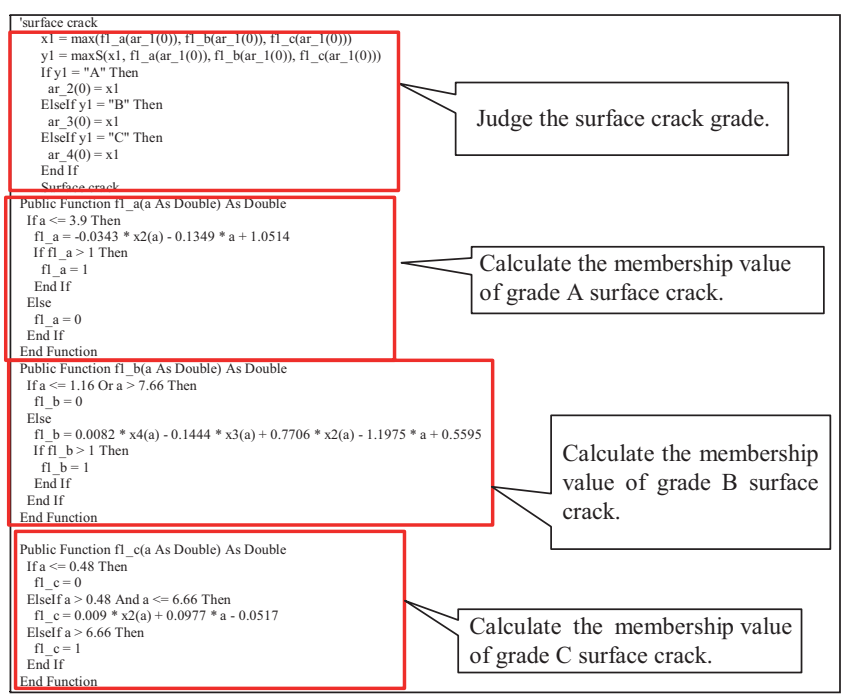

Fig. 19. Program of calculate membership values of each grade.

Because there are two major types of sidewalk pavement, so before the inspection engineer inputs inspecting data, he/she must decide what type the pavement is. Then the inspector can click "input" button to input existing data of the inspecting sidewalk. If the inspector wants to refer specific sidewalk, he/she can click "Find" button to enter road name to get the right information (Fig. 14). If the inspector wants to delete specific sidewalk information, he/she can click "del" button to do it. On the other hand, if the inspector wants to create a new sidewalk inspection data to this system, he/she can just click "addnew" button to do it. Then the system will allow user to

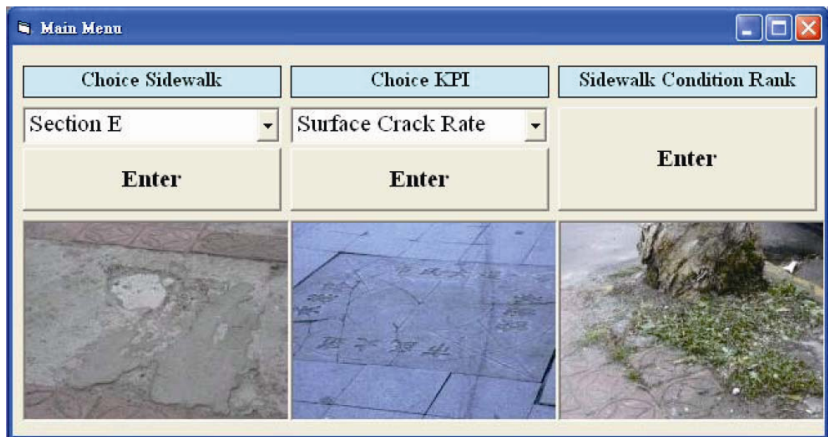

Fig. 20. Analysis information menu.

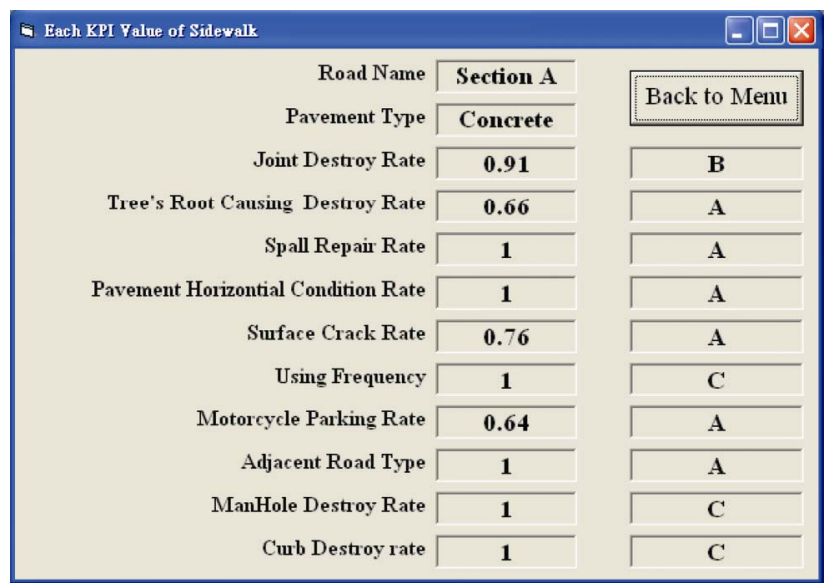

Fig. 21. Grades of KPI membership values for a specific sidewalk.

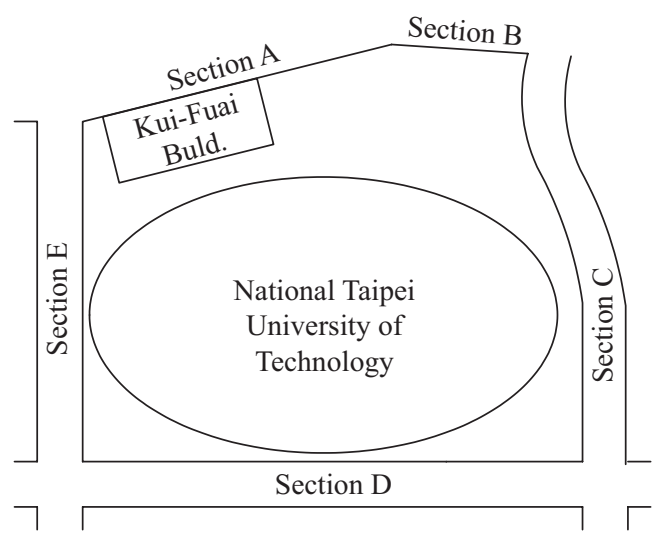

Fig. 22. Selected sidewalk sections.

input general information. Because there are lots of inspection items to input, the PDA screen does not show all items at the whole screen. So this system provides a scroll bar to let user conveniently input by switch screen (Fig. 15). The program codes of "select pavement type" and "addnew" function are shown in Fig. 16.

\section{The Analysis and Display System of PC}

This research uses PC to gather data from PDA to analyze 
Table 10. Statistic and comparing of assessment model result.

\begin{tabular}{|c|c|c|c|c|c|c|c|}
\hline \multirow{2}{*}{$\begin{array}{l}\text { Sidewalk } \\
\text { Section }\end{array}$} & \multicolumn{5}{|c|}{$\begin{array}{l}\text { Statistics of sidewalk } \\
\text { condition and rank* }\end{array}$} & \multirow{2}{*}{$\begin{array}{l}\text { Comparing } \\
\text { result by } \\
\text { people's } \\
\text { survey }\end{array}$} & \multirow{2}{*}{$\begin{array}{l}\text { Comparing } \\
\text { result by } \\
\text { assessment } \\
\text { model }\end{array}$} \\
\hline & $1 \mathrm{st}$ & 2nd & $3 r d$ & 4th & 5 th & & \\
\hline Section A & 5 & 4 & 12 & 10 & 2 & 3 & 3 \\
\hline Section B & 3 & 8 & 10 & 6 & 6 & 4 & 4 \\
\hline Section C & 13 & 10 & 6 & 4 & 0 & 1 & 1 \\
\hline Section D & 12 & 9 & 6 & 5 & 1 & 2 & 2 \\
\hline Section E & 0 & 4 & 4 & 5 & 20 & 5 & 5 \\
\hline
\end{tabular}

*: 1 st- the worst; 5 th- the best

sidewalk's grade. The analysis result can provide sidewalk engineers to make maintenance decision. The critical information is about "To display the grade and the membership value of KPI in each sidewalk", "To display the rank of KPI in each sidewalk", and "To display condition rank of all sidewalks". This research uses Microsoft Visual Basic to design this system on PC and uses Active Database Object (ADO) to assess database. This system can transform database format from PDA to PC. The PC system can read database which transformed from PDA to input membership function to produce analysis information.

Figure 17 is the homepage screen of this PC system. Program user can click "About" button to show system introduction (Fig. 18). If the user clicks "Into main system" button, the screen will show a database management menu which involves: (1) "Database transform"-it can transform database format from PDA to PC, (2) "Read database"- it can read transformed database to PC, and use program function to calculate membership value, and (3) "Show analysis information"- it can show analysis result. Such program code is shown in Fig. 19.

After read database to analyze program, program user can look analysis result in "Analysis Information" frame. The analysis information menu contains 3 parts (Fig. 20). If the user wants to know each KPI value of any inspected sidewalk, he/she can click "Road Name" button to input the road name (Fig. 21). Meanwhile, if any user wants to check each KPI value for all sidewalks, he/she can click "KPI Value for all sidewalks" button to select specific KPI grade. If program user wants to check all sidewalks' condition, he/she can just click "sidewalks condition" button.

\section{V.SYSTEM ILLUMINATION}

In order to illustrate and simulate the reliability of this model, this research collected 33 people's opinions after practice survey to rank the damage situations of 5 selected sidewalks around the campus of National Taipei University of Technology (Fig. 22), and then derives the comparing situation of these sidewalks. Such comparing result is the same as programming result (Table 10). From this illustration, the appropriate performance of this prototype program can be approved.

\section{CONCLUSIONS}

This research creates two separate modules, the first module is developed in a portable PDA system to allow inspectors check and input sidewalk's practice conditions right at the field, the second module is created to transform database of PDA to PC system, and derive the performance situation of inspected sidewalk. In addition, this system can be developed as a sidewalk maintenance management system (SMMS) with cost consideration to help engineers make appropriate maintenance strategy.

\section{REFERENCES}

1. Expert Choice, http://www.expertchoice.com/ (2000).

2. Hiraoka, T., Maeda, H., and Ikoma, N. (Eds.), "Two-stage prediction method of typhoon position by fuzzy modeling-fusion of outline prediction and detailed prediction systems," Proceedings of IEEE SMC '99 Conference on Man, and Cybernetics, Vol. 6, pp. 581-585 (1999).

3. Lin, L., Infrastructure System Management, National Taipei University of Technology, Taiwan (2006).

4. Lin, L. and Jian, C., "A portable sidewalks maintenance management system," Proceeding of the Fifth International Conference on Engineering Computational Technology, Spanish, Paper 77, pp. 1-18 (2006).

5. Lin, L. and Jian, C., "The development of a portable sidewalks maintenance management system," Proceeding of Joint International Conference on Computing and Decision Making in Civil and Building Engineering, Montreal, Canada, pp. 2115-2124 (2006).

6. Ossadnik, W. and Lange, O., "AHP-based evaluation of AHP-software," European Journal of Operational Research, Vol. 118, No. 12, pp. 578-588, 99-110 (1999).

7. Satty, T. L., The Analytic Hierarchy Process, McGraw-Hill, New York (1980).

8. Timothy, J. R., Fuzzy Logic with Engineering Applications, McGraw-Hill International Editions (2000). 